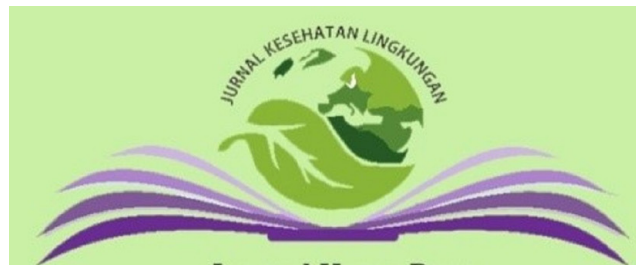

Journal Home Page:

https://e-journal.unair.ac.id/JKL

\section{Jurnal Kesehatan Lingkungan}

Vol. 14 No. 1

DOI: $10.20473 / j$ lkl.vl4il.2022.63-70

ISSN: 1829 - 7285

E-ISSN: 2040 - 881X

\title{
IMPLEMENTATION OF ENVIRONMENTAL SANITATION AND DISINFECTION IN HOSPITALS TO REDUCE THE SPREAD OF COVID19: A LITERATURE REVIEW
}

\section{Devi Anggraini ${ }^{1 *}$, Kusuma Scorpia Lestari ${ }^{1}$}

${ }^{1}$ Department of Environmental Health, Faculty of

Public Health, Universitas Airlangga, Surabaya 60115,

Indonesia

Corresponding Author:

*) devi.anggraini-2017@ffkm.unair.ac.id

\section{Article Info}

Submitted

In reviewed

Accepted

Available Online

\author{
21 September 2021 \\ January 2022 \\ 31 January 2022
}

\section{Abstract}

Introduction: SARS-CoV-2 is a new variant of virus that attacks the human
respiratory tract which was declared by WHO as a Covid19 pandemic. Covid19
transmission through solid surfaces, air, and waste occurring in hospital areas
require disinfection and sanitation monitoring to ensure that new clusters are not
created and outpatients are not infected with the SARS-CoV-2 virus in hospitals.
Discussion: Using literature review method, 11 relevant articles that meet the
inclusion criteria were selected. In the results of the study, there was a collection
of samples in the solid surfaces, air and waste in both medical and non-medical
areas containing SARS-CoV-2 RNA. The common objects where SARS-CoV-2
was discovered include doorknobs, toilet bowls, toilet flush buttons, and medical
devices. In non-medical areas, the objects include computer keyboards, mice, and
monitors. Chlorine-based disinfection for surfaces, monitoring in environmental
sanitation by changing pillow and bedsheets and cleaning tables regularly were
subsequently implemented. Conclusion: The implementation of environmental
sanitation and disinfection is effective in eliminating the SARS-CoV-2 virus
in hospitals. Studies indicated that disinfection is $95 \%$ to $99.99 \%$ effective in
eliminating the SARS-CoV-2 virus. In addition, the SARS-CoV-2 virus was not
discovered in isolation rooms but was located in other public hospital areas.

Keywords : Covid19, SARS-Cov-2, Disinfection, Environmental sanitation, Hospital

Published by Fakultas Kesehatan Masyarakat Universitas Airlangga

\section{INTRODUCTION}

In December 2019, the discovery of the SARSCoV-2 or Covid19 virus that affects the respiratory tract was first discovered in the animal market of Wuhan City, Hubei Province, Central China and spread to various countries (1). At the beginning of the Covid19 pandemic, patient care in hospitals jumped drastically, causing hospitals to be filled with patients infected with Covid19. Since the emergence of the virus, the handling of Covid19 in hospitals has become stricter, as demonstrated in April 2020, where one of the hospitals in Germany screened patients and workers, formed an infection control team, carried out patient separation and conducted hygiene training for health workers (2). The treatment of Covid19 in hospitals, as recommended by the World Health Organization (WHO), is through screening and triage for patients suspected of Covid19, the use of PPE (Personal Protective Equipment) for health workers as well as training, the implementation of disinfection and environmental sanitation in hospitals, waste management and separation of infected and uninfected patients (3).

Indonesia reported 4,223,094 cases of SARSCoV-2 on October 6, 2021 with the number of recovered patients at 4,052,300 individuals (4). According to reports, reinfection had occurred in patients and health workers who have recovered, with reinfection cased discovered in Hong Kong, USA, Belgium, Ecuador and India where $90-91 \%$ of individuals who had been infected with SARSCoV-2 virus had antibodies detected within 4 weeks after infection (5). In a report, a reinfection case in India occurred in July 2020 where a 23-year-old male health worker at a hospital tested positive for SARS-CoV-2. He recovered on October 9, 2020. On November 9, 2020, a test screening conducted as part of the regulations in the hospital, detected SARS-CoV-2 virus in the person (6).

Transmission of SARS-CoV-2 virus is understood to spread through droplets which then attach to the surface of objects. The positive rate of the surfaces in medical-related areas reached $24.83 \%$, with general 
isolation wards and intensive care units at $25.00 \%$ and $37.50 \%$ respectively. In addition, there are five common locations with SARS-CoV-2 virus detected, namely beepers (call button in patient rooms) $(50.00 \%)$, water machine buttons $(50.00 \%)$, elevator buttons $(42.86 \%)$ computer mice $(40.00 \%)$, and phones $(40.00 \%)(7)$. Based on these data, it can be concluded that the virus not only spreads in places where infected patients are located but also in other locations where visitors may mingle and in all parts that are often touched by hospital staff members and outpatients.

Disinfection and environmental sanitation monitoring in hospitals must be carried out to prevent and control the virus so as not to infect other patients who are Covid19 negative. The use of disinfectants using solutions to reduce nosocomial infections in hospitals may be applied with disinfectant-soaked cloth which may reduce bacteria or viruses by $10 \%$. The use of disinfectants may fail if it is not applied properly. An efficiency of up to $100 \%$ is achievable by handling disinfection products appropriately (8). Environmental sanitation applied in hospitals include cleanliness in every hospital area, clean water management, and waste management in hospitals (9).

This study aims to examine the implementation of environmental sanitation and disinfection in hospitals to reduce the spread of Covid19. In addition, it also examines areas commonly contaminated with the Covid 19 virus in the hospital area and the effectiveness of disinfection application in hospitals. This research takes the form of literature review by using secondary data in the form of literature studies from various databases. The literature used is in the form of articles on "environmental sanitation and "disinfection" in hospitals and "Covid19". The literature study was carried in 2020-2021.

\section{DISCUSSION}

Further research is still being conducted to examine transmission of SARS-CoV-2 virus through air. A study conducted at Shahid Mustafa Khomeini Hospital in Ilam Province, Eastern Iran examined 14 samples extracted from air in the hospital ward using a liquid bio sampler impinge and stated that there were 2 samples in the ICU room that was confirmed positive sars-CoV-2 (10-11). Fomite transmission or transmission from touched surfaces (surfaces of objects) was examined with experiments using aerosols and it was discovered that that the SARS-CoV-2 virus survived in aerosols for a duration of 3 hours. The SARS-Cov-2 virus is more stable in plastic and stainless steel than copper and cardboard, and can live for 72 hours (12). Research on fomite transmission conducted in 2020 examined health care units by sampling on the surface and wiping the surface of inanimate objects indicated that out of 26 samples, 2 samples were positive SARS-CoV-2, both collected from the outer surface of CPAP helmets (13). Therefore, regular cleaning is required to eliminate SARS-CoV-2 virus from the surface of objects. In addition, another study discovered that liquid waste of patients (urine and feces) was infected with Covid19 (14). However, further research is required to determine the accuracy of transmission through liquid waste. A study indicated that SARS-CoV-2 was detected in feces of Covid19 patients with first symptoms with lasting approximately 28 days. Another study discovered patients who had positive samples for 33 continuous days after the breathing sample became negative (15). In the study, further prevention was implemented by conducting RTPCR tests on the feces of patients who tested negative for breathing. In addition, disinfection on liquid waste in hospitals was implemented.

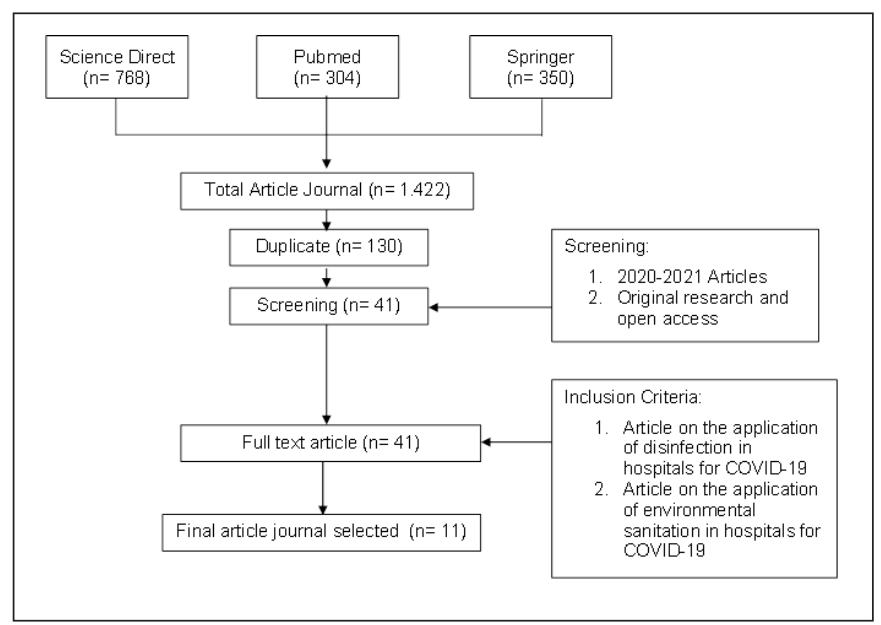

Figure 1. Journal Selection Process

The high rate of transmission encourages the widespread transmission of Covid19 through the formation of clusters or groups, where different types of clusters may emerge, such as family clusters, community clusters, and hospital clusters. This has driven a new cluster classification which now includes a group that has $>5$ cases (16-17). In South Korea, where 134 clusters with 4,033 cases were identified, the clusters are categorized into: small clusters (type I and II), medium clusters (type III) and large clusters (type IV) (18). Clusters that are susceptible to Covid19 infection are clusters in hospitals. Based on reports, Zhongnan University Hospital in Wuhan stated that, at the beginning of the outbreak, there were 138 cases of transmission suspected to occur in $41 \%$ (57/138) patients including 40 health workers (19-20). One of the hospitals in Bukit Tinggi, Indonesia stated that the hospital is a 
non-referral hospital for Covid19 patients, but could not avoid patients who do not show symptoms of Covid19 to receive medical services which prompted transmission from patients without symptoms. Based on these cases, there are $3.84 \%$ of hospital employees were infected with Covid19 (21).

Table 1. Summary of Relevant Articles on The Implementation of Disinfection and Environmental Cleaning Procedure in Hospitals

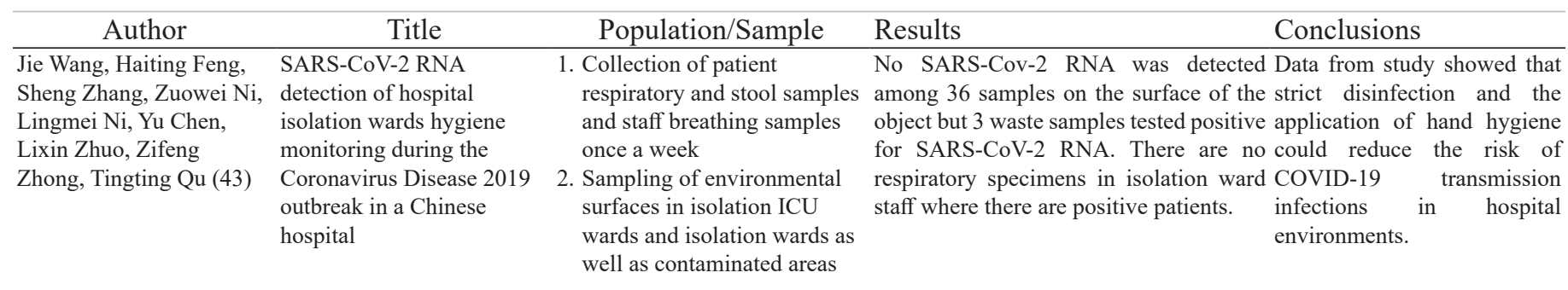

\begin{tabular}{lll}
\hline Katia Razzini, Marta & $\begin{array}{l}\text { SARS-CoV-2 RNA } \\
\text { detection in the air and on } \\
\text { Castrica, Laura }\end{array}$ & $\begin{array}{l}\text { 42 air and surface samples } \\
\text { obtained from different }\end{array}$ \\
$\begin{array}{l}\text { Menchetti, Lorenzo } \\
\text { Maggi, Lucia Negroni, }\end{array}$ & $\begin{array}{l}\text { ward of a hospital in Milan, contaminated and clean areas } \\
\text { Nicola V. Orfeo, Alice }\end{array}$ & Italy \\
$\begin{array}{l}\text { Pizzoccheri, Matteo } \\
\text { Stocco, Stefano Muttini, }\end{array}$ & & \\
Claudia M. Balzaretti (41) & &
\end{tabular}

Caijuan $\mathrm{Xu}$, Jingfen Jin, Application of refined Jianping Song, Yan Yang, management in prevention Meiqi Yao, Yuping Zhang, and control of the Ruiyi Zhao, Zhimei Chen coronavirus disease 2019 (24) epidemic in non-isolated areas of a general hospital

$24.3 \%$ of swab samples were positive, This research shows that strict but none were collected from the clean and systematic structural and area. Positive rates were higher in personal protection and the contaminated sites $(35.0 \%)$ and semi- application of disinfection contaminated areas $(50.0 \%)$ and clean should be applied to reduce areas $(0.0, \mathrm{~Pb}$ 0.05). Contaminated the risk of infection for surfaces are hand sanitizer dispensers medical staff.

$(100.00 \%)$, medical equipment $(50.0 \%)$,

medical device touchscreens $(50.0 \%)$, medical racks $(40.0 \%)$, bed rails $(33.3 \%)$ and door handles $(25.0 \%)$

The absence of COVID-19 infection in Enhanced management the hospital including hospital staff. From strategies for the prevention the use of masks, screening of disease and control of COVID-19 history and disinfection debriefing are infection in non-isolation all $100 \%$ in the hospital, the compliance public hospitals is effective rate of mask use is $73.79 \%$ and the hand and the accuracy of the mask hygiene compliance rate is $40.78 \%$. use and hand hygiene of patients and families need to be further enforced.
Tianxiang Ge, Ye Lu, Shufa Zhengaluation of disinfection Ling Yu, Zuowei,

Yanan Zhou, Lingmei, Tingting Qu, Zifeng Zhong (42) Evaluation of disinfection
procedures in a designated hospital for COVID-19
1. 163 samples were collected from February to April 4.

2. 105 environmental surface samples collected in isolation wards during covid-19 hospitalization of patients

3. 41 waste samples collected from inducts

4. 17 surface sample environments collected from the examination room
A total of 163 samples were collected. During the COVID-19 Out of 122 surface samples, 2 are positive pandemic, the implementation RNA coronavirus, 2 showed severe of disinfection and cleaning of acute respiratory syndrome. One of the the surface of objects needs to flush buttons on the toilet and the other be looked into and tightened collected from the hand basin. 10 waste to reduce the risk from items detected with positive RNA virus COVID-19 transmission. Implementation should be considered in all areas of the hospital.

\begin{tabular}{ll}
\hline Byung-Han Ryu, & Environmental \\
Younghwa Cho, Oh-Hyun & contamination of SARS- \\
Cho, Sun In Hong & CoV-2 during the COVID- \\
Sunjoo Kim, Seungjun & 19 outbreak in South Korea \\
Lee (27) &
\end{tabular}

\section{Byung-Han Ryu,}

Cho, Sun In Hong

Lee (27)
1. Sampling at hospitals A and Hospital A detected SARS-CoV-2 in The hospital surface around B. At hospital A, there were 10 of $57(17.5 \%)$ samples from indoors the patient was contaminated 5 patients with pneumonia in including on ambu bags and infusion bySARS-CoV-2. This study the negative pressure room. pumps. Hospital B, 3 of 22 (13.6) samples refers to strict prevention by At hospital B, 8 patients were from inside the room were positive. The carrying out routine cleaning without symptoms in 2 rooms areas outside the room, i.e. front areas, (environmental sanitation) with 4 beds corridors, and treatment rooms are all and applying disinfection in

2. Some rooms are not cleaned negative in both hospitals. and poorly disinfected. Environmental swabs are taken from indoors and outdoors and tested with real-time RT-PCR to detect SARS-Cov-2 the management of COVID19 management. 


\section{Author}

G. Moore, H. Rickard, D. Stevenson, P. AranegaBou, J. Pitman,

A. Crook, K. Davies, A. Spencer, C. Burton, L. Easterbrook, H.E. Love,

S. Summers, S.R.

Welch, N. Wand, K-A.

Thompson, T. Pottage,

K.S. Richards, J. Dunning,

A. Bennett (28)

Xing-Yi Ge, Ying Pu,

Ce-Heng Liao, Wen-Fen

Huang, Qi Zenge, Hui

Zhouf, Bin Yif,

Ai-Min Wang, Qing-Ya

Dou, Peng-Cheng Zhou,

Hui-Ling Chen, Hui-Xia

Liu, Dao-Miao Xu,

Xiang Chen, Xun Huang

(26)

Guangming Ye, Hualiang Environmental

Lin, Song Chen, Shichan contamination of SARS-

Wang, Zhikun Zeng, Wei CoV-2 in healthcare

Wang, Shiyu Zhang, Terri premises

Rebmann, Yirong Li,

Zhenyu Pan, Zhonghua

Yang, Ying Wang, Fubing

Wang, Zhengmin Qian,

Xinghuan Wang (29)

\section{Population/Sample}

ospital samples were collected across the UK environment: a multi-centre during the first wave of the study conducted during the first wave of the COVID-19 outbreak in England

Evaluation of the exposure risk of SARS-CoV-2 in different hospital environment 2019 coronavirus outbreak. Samples were analyzed using transcription polymerase chain reaction (PCR) and virus isolation test kits. were tested for the nucleic acid

\section{Results}

Conclusions SARS-CoV-2 RNA was detected in 30 Performing effective cleaning $(8.9 \%)$ of 336 from the environmental in reducing the risk of surface. Cycle Threshold values range fomite transmission, low from 28.8-39.1. The number of bacteria is or undetectable RNA virus simultaneously low and suggests that the concentrations in the air cleaning that has been done in 8 hospitals supports accurate guidelines is effective in lowering the risk of SARS- on self-protection.

CoV RNA. Air samples were detected in

4 of the 55 samples taken $<1 \mathrm{~m}$ from four different patients.

Surface samples with 6 different SARS-Cov-2 nucleic acid positive rate Monitoring and disinfecting locations from 3 hospitals with is 7.7\% in COVID-19 wards and 82.6\% SARS-CoV-2 in hospital different levels of protection ICU with COVID-19 patients environments during the COVID-19 pandemic and helping to prevent SARSCoV-2 transmission and to SARS-CoV-2

\begin{tabular}{|c|c|c|c|}
\hline $\begin{array}{l}\text { Li Wei, Wenzhi Huang, } \\
\text { Xiaojun Lu, Yantong } \\
\text { Wang, Linzhi Cheng, } \\
\text { Rong Deng, Haiyan Long } \\
\text { and Zhiyong Zong (31) }\end{array}$ & $\begin{array}{l}\text { Contamination of } \\
\text { SARS-CoV-2 in patient } \\
\text { surroundings and on } \\
\text { personal protective } \\
\text { equipment in a non-ICU } \\
\text { isolation ward for } \\
\text { COVID-19 patients with } \\
\text { prolonged PCR positive } \\
\text { status }\end{array}$ & 2. & $\begin{array}{l}\text { Air sampling from rooms } \\
\text { of } 9 \text { COVID-19 patients } \\
\text { with the disease or PCR } \\
\text { positive }>30 \text { days. } \\
\text { Sampling before and } \\
\text { after a nasopharyngeal/ } \\
\text { oropharyngeal swab } \\
\text { and before and after } \\
\text { nebulization treatment. } \\
\text { Sampling in the patient's } \\
\text { environment and personal } \\
\text { protective equipment (PPE) } \\
\text { of health workers in non- } \\
\text { ICU wards }\end{array}$ \\
\hline
\end{tabular}

Varvara A. Mouchtouri, Michalis Koureas, Maria Kyritsi, Alexandros Vontas, Leonidas Kourentis, Spyros Sapounas, George Rigakos, Efthimia Petinaki, Sotirios Tsiodras, Christos Hadjichristodoulou (30) Zhen Ding, Hua Qian, Bin Xu, Ying Huang< Te Miao, Hui-Ling Yen, Shenglan Xiao, Lunbiao Cui, Xiaosong Wu, Wei Shao, Yan Song, Li Sha, Lian Zhou, Yan Xu, Baoli Zhu, Yuguo Li (32)
Environmental contamination of SARS$\mathrm{CoV}-2$ on surfaces , airconditioner and ventilation systems
Environmental sampling from 3 COVID-19 isolation hospita wards and long-term care facilities with asymptomatic COVID-19 cases.

\section{Toilets dominate} environmental detection of severe acute respiratory syndrome coronavirus 2 in a hospital
626 surface samples at

Zhongnan medical center in

Wuhan swab dakron collected

from 13 hospital function zones, 5 main objects and 3 main PPE
Highly contaminated areas include Good and adequate special intensive care units to treat environmental sanitation and COVID-19 patients $(31.9 \%)$, obstetric strengtheninfectionprevention isolation wards with $\mathrm{NCP}(28.1 \%)$ and training and improve infection isolation wards for NCP (19.6\%). The prevention. most contaminated objects were printers (20.0), desktops/keyboards (16.8) and door knobs $(16.0 \%)$. Both hand sanitizers $(20.3 \%)$ and gloves $(15.4 \%)$ were contaminated PPE.

88 samples were collected from Environmental pollution in frequently touched surfaces and floors in COVID-19 patients with patients' rooms and toilets with 2 patients other patients will be rare if and 1 SARS-CoV-2 positive toilet. All air disinfection is carried out and $(n=34)$ are SARS-CoV-2 negative. The hygiene is strictly applied. 55 samples collected from PPE were all Transmission of SARS-CoV-2 negative. in the air is not possible in non-ICU settings
SARS-CoV-2 was detected on swab Maintaining hand hygiene samples taken from the surface of food and environmental cleaning service areas, hospital wards, sewer and disinfection play a very services, AS filters, sewage treatment important role and is included units and water air samples during as the main key in disrupting research conducted in dealing with the the chain of spread of COVIDCOVID-19 outbreak.

19.
Sampling in toilet and non-toilet 1. environments was conducted in hospital buildings for COVID-19 patients and other environmental factors analyzed. 107 surface samples, 46 air samples, 2 condensate samples, and 2 expired air samples were collected inside and outside 4 isolation rooms with 3 beds.
107 surface samples were collected, The study explained the including 37 samples from toilet, 34 importance of maintaining from other surfaces in isolation room the cleanliness of surfaces and as well as 36 from other surfaces hands in hospitals. outside hospital isolation rooms. There were 4 positive samples including 2 ward door handles, 1 bathroom toilet seat lid, and 1 bathroom door handle. 3 positive but weak i.e. 1 bathroom toilet seat, 1 hard lever bathroom sink and 1 bathroom ceiling grille.

2. 46 air samples included 1 weak sample taken from a corridor that is positively weak. 2 samples of condensate expiration and 2 samples of expiratory air were negative 


\section{Environmental sanitation}

Sanitation procedures carried out in the hospitals include cleaning the administrative areas at least once a day (every 24-hour period), the examination or consultation area 2 times a day, while the operating room is cleaned and disinfected before and after a surgery and the sink is cleaned weekly and monthly (22). The procedures are carried out routinely in hospitals by following the applicable rules and have been applied before the Covid19 pandemic. During the Covid19 pandemic, the environmental sanitation procedures are still applied without any difference when handling Covid19 cases in hospitals. Regular environmental sanitation procedures to reduce the spread of Covid19 is carried out on surfaces that are often touched and surfaces that are rarely touched (23). Frequently touched surfaces such as doorknobs, beds, table surfaces, and light sockets should be frequently cleaned with detergent solutions tailored to the level of contamination (24). Rarely touched surfaces such as ceilings, floors, walls and curtains may be cleaned using detergent solutions. Wipes are also used to clean common surfaces and nonpatient treatment areas as well as wet mopping, dusty curtain replacement and regular sink clean-up (25).

The difference of the implementation of cleaning procedures in areas contaminated with Covid19 lies in the frequency (26). In one of the hospitals in China, the cleaning the object surfaces and health facilities are carried out using $1000 \mathrm{mg} / \mathrm{L}$ of chlorine containing disinfectant 2 times a day, each with an interval of 30 minutes before being wiped with water (27). Hospitals in South Korea perform environmental sanitation procedures by wiping surfaces using 0.1 hypochlorite and clean water but not on a daily basis (28). Hygiene monitoring during the Covid19 pandemic is carried out through control and monitor mechanism in every area of the hospital to avoid transmission to other outpatients and also employees who do not treat positive patients. Applying hygiene protocols to clean surfaces using chlorine for tables, bed rails, and call buttons are recommended to be carried out twice a day (29). The same treatment is conducted by applying environmental sanitation procedures in each area of the hospital by wiping using chlorine liquid (30-31). The implementation of hygiene protocols in hospitals will continue since the pandemic is still present, which means non-Covid19 rooms must be continually monitored as well. The studies discovered positive SARS-CoV-2 RNA in beds and toilet bowls, hence cleaning in the ward areas or patient rooms by replacing sheets and pillows and toilets with $2000 \mathrm{mg} / \mathrm{L}$ of chlorine and preparing a handsanitizer in each patient's room were necessary (32). Toilets must also be maintained since SARS-CoV-2 RNA was also discovered in toilet bowls.

The cleaning procedure conducted by one of the hospitals in China includes daily cleaning of touched surfaces with sodium dichloroisocyanurate solution containing $500 \mathrm{mg} / \mathrm{L}$ of chlorine, with janitors in complete PPE to avoid the possible transmission of SARSCoV-2 (33). The frequency of environmental sanitation procedures differs before and during the Covid19 pandemic. Before the pandemic, cleaning procedures are carried out 1 time a day for administrative areas or waiting rooms and 2 times a day for areas with high touch frequency. However, during the Covid19 pandemic, they are carried out 2 times a day for both high risk and low risk areas to keep all hospital areas in a sterile state.

\section{Disinfection}

Disinfection applied in hospitals not only covers surface disinfection but also air and waste disinfection because they need to be monitored more closely. There needs to be a monitoring of areas in the hospital as well as strict screening for all hospital employees (34). One hospital in Purwokerto, Indonesia indicated that the effectiveness of disinfection to reduce the incidence of nosocomial infection reached $96 \%$ using chlorine (35). In addition, the use of ultraviolet-C disinfection in Taiwan University hospitals which conducted 48-hour trials resulted in a $100 \%$ reduction of bacterial colonies in the observed object, including bedrails, the top of the patient's bedside table, telephones, refrigerator doors, and switches (network switches) (36). The study indicated that the disinfection to eliminate pathogenic bacteria in hospitals was effective in its application. Another study indicated that the $222 \mathrm{~nm}$ UVC method with a time of 30 seconds and effectiveness of up to $99.7 \%$ can only be conducted in an empty room because it has a harmful effect on humans (37). In addition, another study examined the use of disinfection in waste by electrochemical oxidation methods and was able to inactivate the SARS-CoV-2 virus with $95 \%$ effectiveness in 30 seconds and $99.99 \%$ effectiveness for 5 minutes (38).

Based on WHO recommendations, products utilized for disinfection are chlorine-based products which includes formulations of sodium hypochlorite and calcium hypochlorite with concentration of $0.1 \%$ for Covid19 treatment and concentration level of $0.5 \%$ for blood and body fluids with a large volume of $>10 \mathrm{~mL}$ (39). There were no significant differences in the application of disinfection in hospitals before the Covid19 pandemic and during the Covid19 pandemic in terms of the chemicals and methods. However, the frequency of 
the disinfections carried out in each hospital increases to maintain cleanliness and avoid Covid19 clusters in hospitals. Based on the results of research tests, disinfection was conducted using chlorine-containing chemicals with $2 \mathrm{~g} / \mathrm{L}$ sprayed as much as 4 times a day in the surrounding environment such as floors, tables, and beds around contaminated areas and left unused for 30 minutes. Clothing items, bed linens in outpatients, bed linens of Covid19 patients and other objects in the area are mandatory to be sprayed with $75 \%$ ethyl alcohol (40). To ensure safety in the implementation of disinfection, appropriate clothing items must be worn including white coats, N95 face masks, surgical masks, surgical caps, protective glasses and boot covers (41).

Several studies demonstrated differences in the frequency of disinfection, which ranges from 3 times a day, 6 times a day, every 4 hours and every 8 hours (4243). These studies indicated that the effective frequencies to reduce the SARS-CoV-2 virus are every 4 hours and 8 hours, with 4 hours in the isolation rooms and 8 hours of common areas, waste with negative isolation rooms, negative common areas and only positive waste with weak viruses detected (42-43). The use of disinfection in Indonesian hospitals includes disinfection sprayed directly on the surfaces of objects in all rooms such as waiting rooms, emergency wards and other rooms (44).

\section{ACKNOWLEDGEMENTS}

The author would like to express a heartful appreciation to researchers who had conducted the research mentioned in this literature review.

\section{CONCLUSION}

SARS-CoV-2 virus spreads through droplets that may stick to the surface of objects. Therefore, the use of masks in every location both inside the hospital and outside the hospital as well as maintaining distance between visitors is critical to prevent transmission. The most widely identified transmission through surface of objects in hospital area is through the often-touched surface of objects, namely door handles, toilet flush buttons, medical devices, medical shelves and other nonmedical objects, including computer monitors, keyboards, mice, and sinks. In addition, SARS-CoV-2 virus was also identified in the air and liquid waste, hence the need for air disinfection in the hospital environment and liquid waste. The use of disinfection has an effectiveness of up to $95 \%$ to $99.99 \%$ in eliminating SARS-Cov-2 virus. Monitoring and prevention by applying the use of disinfection and sanitation of the environment on a regular basis are important since it proved effective in reducing the spread of SARS-CoV-2 virus in hospitals.

\section{REFERENCES}

1. Wu YC, Chen CS, Chan YJ. The Outbreak of Covid19: An overview. J Chinese Med Assoc. 2020;83(3):217-220. https://doi.org/10.1097/ JCMA.0000000000000270

2. Höring $S$, Fussen $R$, Neusser $J$, Kleines $M$, Laurentius T, Bollheimer LC, et al. Management of a Hospital-Wide Covid19 Outbreak Affecting Patients and Healthcare Workers. SN Compr Clin Med. 2020;2(1):2540-2545. https://doi.org/10.1007/ s42399-020-00597-2

3. World Health Organisation. Infection Prevention and Control During Health Care When Covid19 is Suspected or Confirmed: Interim guidance. Geneva: World Health Organization; 2020. https://apps.who. int/iris/rest/bitstreams/1272420/retrieve

4. Ministry of Health of Republic Indonesia. Reinfection of Covid19. Jakarta: Ministry of Health of Republic Indonesia. https://www.balaibaturaja.litbang. kemkes.go.id/read-reinfeksi-covid19

5. European Centre for Disease Prevention and Control. Threat Assessment Brief: Reinfection with SARS-CoV-2: Considerations for Public Health Response. Stockholm: European Centre for Disease Prevention and Control; 2020. https:// www.ecdc.europa.eu/en/publications-data/threatassessment-brief-reinfection-sars-cov-2

6. Munivenkatappa A, Sahay RR, Deshpande GR, Patil DY, Shete AM, Sapkal GN, et al. A case with SARS-CoV-2 Reinfection from India. Indian J Med Microbiol. 2021; https://doi.org/10.1016/j. ijmmb.2021.09.010

7. Wu S, Wang $Y$, Jin $X$, Tian J, Liu J, Mao $Y$. Environmental Contamination by SARS-CoV-2 in a Designated Hospital for Coronavirus Disease 2019. Am J Infect Control. 2020;48(8):910-914. https:// doi.org/10.1016/j.ajic.2020.05.003

8. De Oliveira ES, Vieira Araujo EH, Ramos Garcia JN, Agostinho F, Almeida Medeiros KK, Paiva Paulino $\mathrm{T}$ de, et al. Disinfectant Use in the Hospital Environment for Microorganisms Control. J Bacteriol Parasitol. 2017;8(5):1000326. https://doi. org/10.4172/2155-9597.1000326

9. World Health Organization and United Nations International Childern's Emergency Fund. Proper Water, Sanitation, Hygiene and Waste Management in Handling the Covid19 Outbreak. Geneva: World Health Organization; 2020. https://www.who.int/ docs/default-source/searo/indonesia/covid19/ who-unicef---air-sanitasi-higiene-dan-pengelolaanlimbah-yang-tepat-dalam-penanganan-wabahCovid19.pdf?sfvrsn=bf12a730_2

10. Kenarkoohi A, Noorimotlagh Z, Falahi S, Amarloei A, Mirzaee SA, Pakzad I, et al. Hospital Indoor Air Quality Monitoring for the Detection of SARS-CoV-2 (Covid19) Virus. Science of the Total Environment. 2020;748(141324):1-5. https://doi.org/10.1016/j. scitotenv.2020.141324

11. Liu J, Liao X, Qian S, Yuan J, Wang F, Liu Y, et al. Community Transmission of Severe Acute Respiratory. Emerg Infect Dis. 2020;26(6):13201323. https://doi.org/10.3201/eid2606.200239 
12. Doremalen NV, Bushmaker $\mathrm{T}$, Morris $\mathrm{DH}$, Holbrook MG, Gamble A, Williamson BN, et al. Aerosol and Surface Stability of SARS-CoV-2 as Compared with SARS-CoV-1. New England J Med. 2020;384(1):1564-1567. https://doi.org/10.1056/ NEJMc2004973

13. Colaneri M, Seminari E, Novati S, Asperges E, Biscarini S, Piralla A, et al. Severe Acute Respiratory Syndrome Coronavirus 2 RNA Contamination of Inanimate Surfaces and Virus Viability in a Health Care Emergency Unit. Clin Microbiol Infect. 2020;26(8):1094.e1-1094.e5. https://doi. org/10.1016/j.cmi.2020.05.009

14. World Health Organization. Transmission of SARSCoV-2: Implications for Infection Prevention Precautions. World Heal Organ. Geneva: World Health Organization; 2020. https://www.who.int/ news-room/commentaries/detail/transmission-ofsars-cov-2-implications-for-infection-preventionprecautions

15. Wu Y, Guo C, Tang L, Hong Z, Zhou J, Dong X, et al. Prolonged Presence of SARS-CoV-2 Viral RNA in Faecal Samples. Lancet Gastroenterol Hepatol. 2020;5(5):434-435._http://dx.doi.org/10.1016/ S2468-1253(20)30083-2

16. Liu C, Liu Z, Sun L, Zhang K, Sun Y. A Familial Cluster of Covid19 Infection in a Northern Chinese region. J Infect Public Health. 2021;14(9):11271132. https://doi.org/10.1016/j.jiph.2021.07.011

17. Furuse Y, Sando E, Tsuchiya N, Miyahara R, Yasuda I, Ko YK, et al. Clusters of Coronavirus Disease in Communities. Emerg Infect Dis. 2020;26(9):13-16. https://doi.org/10.3201/eid2609.202272

18. Choi Y-J, Park M, Park SJ, Hong D, Lee S, Lee K-S, et al. Types of Covid19 Clusters and Their Relationship with Social Distancing in the Seoul Metropolitan Area, South Korea. Int J Infect Dis. 2021;106(1):363-369._https://doi.org/10.1016/j. iiid.2021.02.058

19. Wang D, Hu B, Hu C, Zhu F, Liu X, Zhang J, et al. Clinical Characteristics of 138 Hospitalized Patients with 2019 Novel Coronavirus-Infected Pneumonia in Wuhan, China. JAMA. 2020;323(11):1061-1069. https://doi.org/10.1001/jama.2020.1585

20. Shin J, Chocron R, Rea T, Kudenchuk P, McNally $B$, Eisenberg M. Merits of Expanding the Utstein Case Definition for Out of Hospital Cardiac Arrest. Resuscitation. 2021;158(1):88-93. https://doi. org/10.1016/j.resuscitation.2020.10.041

21. Ulfah S, Candi C, Darmawan ES. Risk Factors of Covid19 Transmission. 2020. https://doi. org/10.26911/the7thicph-FP.01.04

22. Spruce L. Back to Basics: Environmental Cleaning Hazards. AORN J. 2017;106(5):424-432. https:// doi.org/10.1016/j.aorn.2017.08.013

23. Departement of Health of Australia. Environmental Cleaning and Disinfection Principles for Covid19. Canberra: Departement of Health of Australia. www.health.gov.au

24. Xu C, Jin J, Song J, Yang Y, Yao M, Zhang Y. Application of Refined Management in Prevention and Control of The Coronavirus Disease 2019
Epidemic in Non-Isolated Areas of A General. Int J Nurs Sci. 2020;7(2):143-147. https://doi. org/10.1016/j.jinss.2020.04.003

25. Noh JY, Song JY, Yoon JG, Seong H, Cheong HJ, Kim WJ. Safe Hospital Preparedness in the Era of Covid19: The Swiss Cheese Model. Int J Infect Dis. 2020;98(1):294-296. https://doi.org/10.1016/j. iiid.2020.06.094

26. Ge X-Y, Pu Y, Liao C-H, Huang W-F, Zeng Q, Zhou $\mathrm{H}$, et al. Evaluation of the Exposure Risk of SARSCoV-2 in Different Hospital Environment. Sustain Cities Soc. 2020;61(102413):1-7. https://doi. org/10.1016/j.scs.2020.102413

27. Ryu B, Cho Y, Cho O, Hong SI. Contamination of SARS-CoV-2 during the Covid19 Outbreak in South Korea. Am J Infect Control. 2020;48(8):875-879. https://doi.org/10.1016/j.ajic.2020.05.027

28. Moore G, Rickard H, Stevenson D, Aranega-bou P, Pitman J, Crook A, et al. Detection of SARSCoV-2 within the Healthcare Environment: A MultiCentre Study Conducted during the First Wave of the Covid19 Outbreak in England. J Hosp Infect. 2021;108(1):189-196. https://doi.org/10.1016/j. jhin.2020.11.024

29. Ye G, Lin H, Chen S, Wang S, Zeng Z, Wang W, et al. Environmental Contamination of SARS-CoV-2 in Healthcare Premises. 2020;81(2):e1-e5. https:// doi.org/10.1016/.j.jinf.2020.04.034

30. Mouchtouri VA, Koureas M, Kyritsi M, Vontas A, Kourentis L, Sapounas $S$, et al.Contamination of SARS-CoV-2 on Surfaces, Air-Conditioner and Ventilation Systems. Int J Hyg Environ Health. 2020;230(113599):1-3. $\quad$ https://doi.org/10.1016/j. ijheh.2020.113599

31. Wei L, Huang W, Lu X, Wang $Y$, Cheng L, Deng $\mathrm{R}$, et al. Contamination of SARS-CoV-2 in Patient Surroundings and on Personal Protective Equipment in a Non-ICU Isolation Ward for Covid19 Patients with Prolonged PCR Positive Status. Antimicrob Resist Infect Control. 2020;9(1):1-5. https://doi. org/10.1186/s13756-020-00839-x

32. Ding Z, Qian $\mathrm{H}, \mathrm{Xu} B$, Huang $\mathrm{Y}$, Miao $\mathrm{T}$, Yen $\mathrm{H}$, et al. Toilets Dominate Environmental Detection of Severe Acute Respiratory. 2021;753(141710):1-8. https://doi.org/10.1016/j.scitotenv.2020.141710

33. Steensels D, Oris E, Coninx L, Nuyens D, Delforge $M-L$, Vermeersch $P$, et al. Hospital-Wide SARSCoV-2 Antibody Screening in 3056 Staff in a Tertiary Center in Belgium. JAMA. 2020;324(2):195-197. https://doi.org/10.1001/jama.2020.11160

34. Maryani M, Cahyono T. Studi Efektifitas Disinfeksi dan Sterilisasi dalam Menurunkan Angka Kuman Alat Set Medikasi di Rumah Sakit Wijayakusuma Purwokerto Tahun 2015. Bul Keslingmas. 2016;35(1):79-81. https://doi.10.31983/ keslingmas.v35i1.3081

35. Yang J-H, WuU-I, TaiH-M, Sheng W-H. Effectiveness of an Ultraviolet-C Disinfection System for Reduction of Healthcare-Associated Pathogens. J Microbiol Immunol Infect. 2019;52(3):487-493. https://doi. org/10.1016/j.jmii.2017.08.017

36. Kitagawa H, Nomura T, Nazmul T, Omori K, 
Shigemoto N, Sakaguchi T, et al. Effectiveness of 222-nm Ultraviolet Light on Disinfecting SARSCoV-2 Surface Contamination. Am J Infect Control. 2021;49(3):299-301. https://doi.org/10.1016/j. ajic. 2020.08 .022

37. Tu Y, Tang $W$, Yu L, Liu Z, Liu Y, Xia H, et al. Inactivating SARS-CoV-2 by Electrochemical Oxidation. Sci Bull. 2021;66(7):720-726. https:// doi.org/10.1016/j.scib.2020.12.025

38. World Health Organization. Cleaning and Disinfection of Environmental Surfaces in the Context of Covid19: Interim Guidance. Geneva: World Health Organization; 2020. https://www. who.int/publications-detail-redirect/cleaning-anddisinfection-of-environmental-surfaces-inthecontext-of-Covid19

39. Millar BC, Moore JE. Re-purposing of Domestic Steam Disinfectors Within the Hospital-at-Home Setting: Reconciliation of Steam Disinfector Thermal Performance Against SARS-CoV-2 (Covid19), Norovirus and Other Viruses' Thermal Susceptibilities. Infect Dis Heal. 2021;26(2):156159. https://doi.org/10.1016/j.idh.2021.01.001

40. Holdsworth J, Preston A, Gentile P, Rider P, Yallew W, Juno Z. Process for Disinfection of
N95 Respirators During Covid19 Utilizing Sterile Processing Department: A Single Center Acute Care Hospital. Am J Infect Control. 2021;49(4):489-491. https://doi.org/10.1016/j.ajic.2020.12.004

41. Razzini K, Castrica M, Menchetti L, Maggi L, Negroni L, Orfeo N V, et al. SARS-CoV-2 RNA Detection in the Air and on Surfaces in the Covid19 Ward of a Hospital in Milan, Italy. Sci Total Environ. 2020;742(140540):1-7. https://doi.org/10.1016/j. scitotenv.2020.140540

42. GeT, LuY,ZhengS, ZhuoL, YuL, NiZ, etal. Evaluation of Disinfection Procedures in a Designated Hospital for Covid19. Am J Infect Control. 2021;49(4):447451. https://doi.org/10.1016/j.ajic.2020.08.028

43. Wang J, Feng $\mathrm{H}$, Zhang S, Ni Z, Ni L, Chen Y, et al. SARS-CoV-2 RNA Detection of Hospital Isolation Wards Hygiene Monitoring During the Coronavirus Disease 2019 Outbreak in A Chinese Hospital. Int J Infect Dis. 2020;94(1):103-106. https://doi. org/10.1016/j.ijid.2020.04.024

44. Athena A, Laelasari E, Puspita T. Pelaksanaan Disinfeksi dalam Pencegahan Penularan Covid19 dan Potensi Risiko terhadap Kesehatan di Indonesia. J Ekol Kesehat. 2020;19(1):1-20. https://doi.org/10.22435/jek.v19i1.3146 